\title{
State and future of the 'citadel' and of the heterodoxies in economics: challenges and dangers, convergences and cooperation
}

\author{
Wolfram Elsner* \\ Professor of Economics, University of Bremen, Germany
}

This keynote reflects on the phased-out original neoclassical research program and the dominance of originally heterodox issues and questions, all beyond the 'optimality and equilibrium of the market economy', in modern cutting-edge economic research. This provides opportunities for heterodoxies and a number of severe internal consistency problems in the current mainstream - between their serious research in terms of complexity, dynamics, evolution, institutions and political economy, which they share with the different heterodoxies, and the ideological mantras they keep sticking to in mass teaching, textbooks, commercial research, policy advice and media statements. The severe financial and comprehensive crises have not only left the mainstream largely unswayed, but have rendered economics an even more contested area. The ideological function of the mainstream for the existing economic system seems to have become even more pronounced. On top of that, there is a comprehensive and fatal counterattack against a potential pluralism of ideas and theories and paradigmatic competition, put forward against the heterodoxies and for ideological cleansing of the discipline, spurred on in the disguise of ranking games. The conception and methodologies of the evaluation and ranking procedures have been proved to be fundamentally mistaken and flawed, but are nevertheless implemented against heterodox thinking worldwide. Examples are given throughout the note. Against this background, this keynote reflects about the status of the heterodoxies and current opportunities and ways to establish a relevant, real-world and useful economic discipline through cooperation and proactive pluralism.

Keywords: neoclassical economics, GET, evolutionary economics, institutional economics, post-Keynesian economics, complexity economics, real-world economics, heterodox economics, economic paradigms, economic teaching, pluralism, microfoundations of macro, macrofoundations of micro

JEL codes: $A 1, A 2, B 0, B 5, C O$

\section{THE NEOCLASSICAL 'MAINSTREAM': AN EXHAUSTED RESEARCH PROGRAMME}

The neoclassical economic 'mainstream', or 'orthodoxy' - the 'citadel' - is not in particularly good shape. Its neoclassical core research programme had started quite

\footnotetext{
* President of the European Association for Evolutionary Political Economy (EAEPE); the author is grateful to Heinz Kurz, University of Graz, Austria, for a discussion on the subject and for providing me with some of his own material on the field. This is a revised version of a keynote held at the 1st World Keynes Conference: 'Attacking the Citadel', Izmir, Turkey, 26-29 June 2013.
} 
pretentiously in the mid and late nineteenth century as the would-be 'crest' of the social sciences, a true science, as serious as 'the' science, physics. A social physics, establishing the optimal, unique and stable equilibrium of 'the market economy', beyond any normativity and societal and political dispute.

Despite repeated warnings even by physicists and mathematicians (among them Henri Poincaré), early neo-classicists developed close analogies to classical mechanics, drafting the economy as a closed, presumably non-dissipative system, regularly being in some predetermined unique and 'perfect' stable equilibrium - if not disturbed by exogenous shocks. A system theory (at least) of prices and quantities of a decentralized individualistic economy, with an alleged self-equilibration capacity like a gas in a closed container. And apparently the modern, formalized proof of the older ideas of the Scottish Enlightenment and of Classical Political Economy: decentralization, individualism, 'invisible hand', and spontaneous order. This should have had a brilliant future.

Its formalization, however, was contested, until the 1930s by a plurality of economic approaches - Marxian political economy, the then new Veblenian evolutionary and institutional economics (itself supported by the pragmatist philosophy), Schumpeterian development and innovation economics, multi-sectoral growth, disequilibrium growth, and business-cycle approaches (for example, the Kiel School), etc. - but it nevertheless tried to serve previously in the Great Depression as the ideology of the powerful and ruling, of letting 'the markets' go (letting them be used by their most powerful agents). And after its obvious failure then it was, of course, further contested by Keynes and Keynesianism.

The very idea of an exact science-like mathematical system with an inherent tendency towards a single, predetermined equilibrium somehow remained attractive and supported, though, first from an internal scientific and methodological perspective (its math was considered cutting-edge then), and, second, it was also (apparently) externally required by powerful economic and political forces. Samuelson eventually translated the then more recent state of the physical arts (including elements of thermodynamics) into economics in his Foundations in 1947.

But as we know basically since the 1970s, after Bertalanffy and Prigogine, Kapp, Georgescu-Roegen, the so-called 'Mirowski Debate', Foley, P. Chen, and many others, these foundations have never been really solid: on the one hand, inapplicable to what is in fact an extremely open, energy-importing, 'entropic', complex, evolutionary system, and on the other hand in parts inconsistent among themselves (see also, for example, Wellhöner 2002).

But since the Foundations, the neoclassical mainstream pretends - that is, the average economist believes - that (1) they may trust that there is the perfect proof of the 'perfect market economy' laid down 'somewhere there' in the mathematical-economic literature; (2) further, that the ideal 'market' at least resembles the markets outside, and that real markets basically can be designed according to the ideal; and (3) they may apply the economics of a crossing of two curves in an ideal partial-market model without hesitation in their (i) mass teaching, (ii) research, (iii) applied contract research, (iv) policy advice, (v) media feeding, and (vi) everyday narratives.

In fact, those who formed up to exactly establish the Walrasian idea of a simultaneous, unique, predetermined, and stable General Equilibrium (GE) across $n$ partial markets - namely Arrow, Debreu and others - approached the limits of the original Walrasian neoclassical research programme surprisingly fast. They found (and proved) that such an equilibrium of isolated maximizing individual agents would generally be possible under certain conditions, but not particularly a uniquely identifiable one, let 
alone a stable and self-stabilizing one. On the contrary, the proofs of Sonnenschein, Mantel and Debreu in the early 1970s - that there typically is no unique stable equilibrium, except in very special cases - demonstrated the narrow limits, and, in fact, somehow the end, of the neoclassical research programme.

Many critical economists have called General Equilibrium Theory (GET) conceptually and mathematically simplistic and reductionist (see, for example, Foster 2005), merely designed to attain an equilibrium and apply a certain math (constrained maximization, the Lagrangian and Hamiltonian algorithms, $n$-dimensional differential equation systems), and, in fact, the very simplistic, 'autistically' maximizing agent provides too little 'structure' to allow for more, and more substantial results.

On top of that, inasmuch as close-to-ideal, non-regulated 'markets' - in the reality of imperfect information, direct complex interdependencies, and power - destroy themselves faster than we can often comprehend, also GET had to end in a paradox result: while reclaiming 'perfect' individual freedom, decentralization and spontaneity at the outset, a Walrasian GE turned out to be feasible, if at all, with most uniform individuals only (having all the same preference functions, the 'representative' agent eventually) and with a perfectly centralized and autocratic governance, the Walrasian auctioneer.

Nowadays, of course, we know more about topologies, net structures and the dependence of the results, in decentralized systems, on local or global knowledge, local or global interactions, etc.; and, since Albin/Foley (1998) and many others, we know that a stable equilibrium outcome of a non-regulated 'market economy' is logically possible even under conditions of direct and only local interaction, but overall with less probability than finding a dust corn in the universe.

In all, since the factual early end of the original neoclassical GET research programme, the alleged solid foundation of an economics of a 'market economy', as the culmination and end of history, had turned out to be virtually non-existent. Mainstream economics should have been rebuilt from scratch thereafter.

But, in fact, that result was not shouted from the rooftops, but kept in silence. The mainstream pretended that neoclassical 'normal science' could be continued, and GE (and DSGE) models, in fact, largely defined mainstream normal science. Furthermore, the average teaching, researching and advising economist, and his average victim - the economics and business bachelor and master student - the interested business corporation, think tank, public administration, and politician - continued to believe that there still exists a perfect proof of the market economy, that it is required and prescribed to be taught for good reason, and that they may apply it in research, advice, media statements and everyday narratives.

\section{MAINSTREAM RESEARCH: THEMES AND QUESTIONS THAT WERE ORIGINALLY HETERODOX}

But all the critics' critiques were on the table again after the 1970s and 1980s, and more viable than before. These were the decades-long critiques from the evolutionaryinstitutional, radical political-economic, neo-Schumpeterian and post-Keynesian heterodoxies - that is, old and new critiques at both the production and demand sides of a societal procurement process, and of a decentralized spontaneous mechanism (called a 'market'). The critiques included static-aggregation fallacies and negative unintended consequences of all kinds and critical circular-flow issues à la Sraffa (1926) and Keynes (1936), increasing returns à la Allyn Young (1928), preference orderings, calculability 
and 'rationality' (for example, Allais's paradox of 1953), critical information, heterogeneous interacting agents, and other complexity issues such as historical time, cumulation and path-dependence, over-complexity, complexity reduction, and entropy issues, topology and network structures, and wicked system behaviours, etc. - from Keynes, Schumpeter, Simon, Georgescu-Roegen, Kapp, and many others. A more or less heterodox complexity economics emerged.

And since then, economic research - even of people considering themselves neoclassical or mainstream - increasingly moved to formerly heterodox themes and questions, ignoring that the aspired optimum-equilibrium interpretations of their results no longer had a viable foundation. Long-standing heterodox themes and issues turned out, whether openly acknowledged or not, to be the more rewarding, requiring more advanced and demanding methods, and providing higher academic reputation - up to the level of some recent economics Nobel prizes (like those for the game theorists, for A. Sen, D. Kahneman, V. Smith or E. Ostrom).

Among the critical heterodox research issues have figured, as said, monopolistic and oligopolistic interaction and strategy, public goods and the Commons, externalities and all kinds of more or less wicked social coordination and dilemma problems, incomplete, imperfect and asymmetric information, strong uncertainty, direct interdependence, net technologies and network externalities, information openness, fallacies of aggregation (or of composition) of all kinds, historical time, cumulative process, and lock-in, complex structures and evolutionary process, multiple equilibria and emergent structure, social rules and institutions, and so forth.

\section{A HETERODOX MISUNDERSTANDING: THE MAINSTREAM DOES NOT ADAPT OR DISSOLVE - AN ASTOUNDING METHODOLOGICAL AND SUBSTANTIAL TENACIOUSNESS INSTEAD}

Against this background, some heterodox economists have concluded a substantial change, even dissolution, of the 'citadel'. Sheila Dow, John Davis, Tony Lawson, Roger Backhouse, David Colander and others have suggested that not only is the mainstream somehow fragmenting, it is also dissolving, and that there may thus be more pluralism emerging in the economics discipline. Fred Lee and I, in some edited special issues on ranking in economics, have disagreed with this (see, for example, Elsner/Lee 2008; Lee/Elsner 2010).

What we observe, rather, appears to me to be an unprecedented 'flexibility' of the mainstream. In classical logical epistemology, this has been termed immunization or Model-Platonism.

Recently, Jacob Kapeller, in his Vienna dissertation (2012) and in an article (2013), has overhauled that classical and somewhat undervalued epistemological critique of the 1950s and 1960s neoclassical mainstream that was termed Model-Platonism then (developed by economist and philosopher Hans Albert). Kapeller has modernized the basic analysis of the axiomatic-propositional logic of neoclassical economics, developed over decades to immunize it against conflicting empirical evidence. He not only confirms its widespread thought-experimental style and apriorism, he also applies it to recent developments such as behavioural finance and the mainstream parts of experimental economics. Furthermore, he shows how the neoclassical epistemology has modernized itself by signifying their models as devices for story-telling, while, however, maintaining their normative 'superior insights' - utility maximization, profit maximization and market equilibrium - where they force their specific research insights to fit in. 
Against that background, finally, the post end-of-GET mainstream has developed a surprising axiomatic variation and considerable oscillations in informational content - ranging from pure thought experiment to a completely unrestricted theory of everything - altogether a peculiar, vague and obscure no-man's-land, but with ever-stronger (crypto-) normative and political aspirations. A powerful tool-set for immunization, according to Kapeller, and a self-legitimation in the contested discipline of economics - and for imperialism across the social sciences and beyond.

A typical statement of the untainted self-confidence of the mainstream is given by economist Edward Lazear:

Economics is not only a social science, it is a genuine science. Economists use the construct of rational individuals who engage in maximizing behavior. Economic models adhere strictly to the importance of equilibrium as part of any theory. Finally, a focus on efficiency leads economists to ask questions that other social sciences ignore. These ingredients have allowed economics to invade intellectual territory that was previously deemed to be outside the discipline's realm. (Lazear 2000, QJE, 99; cited in Kapeller 2013: 214)

Another instance of swollen over-confidence is Robert Lucas who - after having received the Nobel Prize in 1995 - released statements such as: ${ }^{1}$ '[the] central problem of depression prevention has been solved' (Lucas 2003: 1) and 'there have never been any new paradigms or paradigm changes or shifts [in economics] ... [it is all about] supply and demand, people maximizing markets (Lucas 2004: 15). (For more detail, see, for example, Kurz 2010.)

\section{THE FINANCIAL CRISIS DAMAGES THE REPUTATION OF ECONOMICS OUTSIDE ACADEMIA - BUT LEAVES MAINSTREAM ECONOMICS UNSWAYED}

The political recipe given by the mainstream of neoclassically inspired and largely 'neoliberal' 2 economists (which, of course, is not an imperative nexus) for nearly 40 years has been a 'one size fits all' simplistic postulate: 'De-régularisez! Privatisez! Le marché va de lui-même'. These oversimplifications leave no proper room for the true complexity of reality, and in this way contribute instead, paradoxically, to the overcomplexities and overturbulence generated in a deregulated market economy (we may remember Ashby's law). It did not, and could not foresee financial fragility, turbulence, risk accumulation, herd behaviour, end-game effects or 'panickiness', it did not anticipate the financial crisis that started in 2007, and still does not have a clue what caused it. We remember the hypes of the theoretically justified speculation industry, claiming inherent tendencies of financial markets towards the 'average' and equilibrium, based on the Brownian motion and presumed normal distributions of values in the 'markets'. We also saw their inventors, Merton and Scholes, receiving the Nobel prizes in 1997.

1. I owe the quotes from Lucas to Heinz Kurz, who provided them in another Keynote at the 1st World Keynes Conference, Izmir, Turkey, June 2013, and provided me with his slides.

2. Note that, in fact, neoclassical economics has little to do with classical political economy, and that, similarly, 'neo-liberalism' does appear to be neither 'neo' (new) nor in any reasonable sense liberal, as a result of its socio-economic consequences, the self-destruction and powerization of markets, and its redistributive and governmental consequences, as we see in the practices of governments since 2008 . 
And they still just stick to their fundamentalist mantras: Do more of the same; if it does not work, do even more of the same; if the situation deteriorates, do ever more of the same; and if the patient dies away, you haven't done enough of the same. The social costs of this are exploding currently (see, for example, Ramazzotti et al. 2012).

And, after a short period of irritation and uncertainty, they have invented the states and governments as the 'true' causes of the crises, generating new story-telling and coining new 'enabling myths'.

The financial meltdown has caused and aggravated severe food and resource, climate, health, social, political, and moral crises, and indeed, wherever we look, there are people, organizations and forces already there that have been fed over four decades to grow to become systemic, with balances bigger than the GDPs of their nations, too big to fail, and even too big to jail. (Even where their frauds, bribes and predations against the simple consumer, house owner or SME have been proven, they pay tens of billions to avoid a final court sentence.) They are, therefore, saved and provided with a full comprehensive 'life insurance' and a 'social safety net' by the governments - to be paid by future generations of taxpayers, savers, and wage and pension receivers.

A famous joke told by Franco Modigliani, Nobel laureate, in his lecture 'My evolution as an economist', in March 1987, thus appears quite topical again in the era of 'neo-liberalism':

A surgeon, an engineer and an economist are discussing which of the three disciplines would be the oldest: The surgeon spoke first and said, 'Remember at the beginning when God took a rib out of Adam and made Eve? Who do you think did that? Obviously, a surgeon.' The engineer was undaunted by this and said, 'You remember that God made the world before that. He separated the land from the sea. Who do you think did that except an engineer?'

'Just a moment,' protested the economist, 'before God made the world, what was there? Chaos. Who do you think was responsible for that?' (Modigliani 1987: 115)

In fact, mainstream economics has neither been particularly successful in contributing to the solution of the exploding problems of mankind; it has, rather, contributed to their aggravation - as far as an academic science can be considered responsible here.

And, having worked outside academia in economic development for 10 years, I may say from own experience that, in general, and for good reason, mainstream economics has a rather bad reputation 'outside', with practitioners, entrepreneurs, etc. - and mostly also with our colleagues from business studies and the business schools.

But there is no doubt that it is always welcome and appreciated as an ideology provider for big finance, big business, corporate lobby associations and think tanks, and their political representatives; but rarely as a provider of practically useful knowledge for business or political strategy in really critical situations, when it is precisely mainstream economists that typically stick to their mantras.

The financial crisis was another major setback for the reputation of the 'citadel' in the minds of the general public. The major intellectual print media - less in their printed versions but in their online op-ed sites - were particularly overt and radical in that respect for some time. For instance, physicist and economist Marc Buchanan (2008) argued in a New York Times op-ed site piece that economics is the only scientific discipline that still is not modern, since its mainstream is not complex but simplistic with its dominant market-optimality and equilibrium vision. And even the British Times stated: 'Economists are the forgotten guilty men. Academics - and their mad theories - are to blame for the financial crisis. They too deserve to be hauled into the dock' (Kaletsky 2009a). 
Similarly, The Financial Times had a lengthy article about the 'uselessness of most "state of the art" academic monetary economics' (Buiter 2009). Also, the Scientific American had an article with the headline 'The economist has no clothes', arguing that mainstream economics has no proper world view to comprehend, articulate and address the most basic human problems, let alone to tackle and solve them (Nadeau 2008).

Many other critical statements and declarations of economists have come out since the implosion of the financial bubble. Just one shall be mentioned: David Colander, Hans Foellmer, Alan Kirman and other well-known complexity economists launched the so-called Dahlem Report (2009), entitled 'The financial crisis and the systemic failure of academic economics'.

Nevertheless, mainstream economics is still neatly interwoven with the most powerful ruling forces in big finance, big business, big media, big administration and big politics - the big 5 - and still occupies nearly all political and administrative power positions designed for economists, as will be illustrated below.

\section{THE 'COGNITIVE DISSONANCE' OF THE MAINSTREAM}

So the 'Ivory tower [remains] unswayed by crashing economy', as Patricia Cohen stated in The New York Times in 2009, rightly forecasting that 'The basic curriculum will not change'. So it has rightly been argued by others that the dominant group of neoclassical 'neoliberal' 'believers in laissez faire' have responded to the shock to their worldview from the crisis in a manner that can be described as cognitive dissonance (Kessler 2010): as the real-world 'disconfirmed' their deeply-held beliefs, they responded with denial. And, as said, after a short phase of irritation, they forgot about the explosion of private fictitious money-capital and Ponzi systems, and redefined the state debt which had exploded after banks being flooded with taxpayers' money, after reinforced austerity policies, and persistent real-economic slack - to be the true cause of the problem.

We may call it cognitive dissonance or schizophrenia. The feminist economist Susan Feiner chose to call it autism (as the post-autistic movement of economics students has done for many years): 'Psychiatrists define autism as "a pervasive development disorder of children, characterized by impaired communication, excessive rigidity, and emotional detachment." Sounds like economics to me' (Feiner 2008).

Heterodox economist Thomas Palley has recently termed the phenomenon of mainstream response that keeps things the same as gattopardo economics, which 'adopts ideas developed by critics of mainstream economics, but ... does so in a way that ignores the thrust of the original critique and leaves mainstream analysis unchanged. ... [It] makes change more difficult because it deceives people into thinking change has taken place. By masquerading as change, it crowds-out space for real change' (Palley 2013: 193).

So the tricky mechanism of the 'citadel' is that, while they generate all kinds of interesting and substantial research output, often of value for heterodoxies, often close to heterodox results, and often using methods heterodoxers use as well, they either force them back into the normative frame of their 'higher insights', as mentioned, the optimum-equilibrium-market mantra, or put them under a tacit quarantine that leaves their mass teaching, their research, advice, etc., and - last but not least their faculty recruitment policies unaffected. 
I have endeavoured for years to avoid any conspiracy theory here, but I came to the conclusion that there is a residual that cannot be explained without referring to an ideological function of mainstream economics: the mainstream appears the most important provider of ideology for the most powerful vested interests - in spite of much SME rhetoric - and for political regression towards unrestricted power structures in the 'markets', and resulting income and wealth distributions that indeed have turned out to be worse than ever.

Taking into account such ideological function, you may tell what my personal delimitation of the realms of mainstream and heterodoxies would be with respect to the Hayekian brand of Austrian Economics and related evolutionism, or some marketeuphoric strand of neo-Schumpeterianism...

\section{THE MODERN MAINSTREAM (MICRO-) ECONOMIC TEXTBOOK: A PECULIAR SCHIZOPHRENIC PHENOMENON}

Old economists often get enjoyably radical, as Ronald Coase indicates, when he stated recently:

Economics as currently presented in textbooks and taught in the classroom does not have much to do with business management, and still less with entrepreneurship. The degree to which economics is isolated from the ordinary business of life is extraordinary and unfortunate. (Coase 2012)

Indeed, established textbooks mostly follow a schizophrenic overall argument: the basics of the 'perfect market economy', in the reduced form of the partial market equilibrium, remain untouched in their first chapters, while an increasing number of chapters, added more recently to the established textbooks, present all kinds of complexity issues and approaches 'on top' as exemptions, deviations, specific cases, peculiarities, add-ons, or sometimes even as 'other views'. In this way, overall, they imply that the complex real world basically leaves the ideal of a 'market' untouched. And while any of the settings of those chapters added in the last two or three decades would make the 'market' model of the first chapters explode (or implode?), the message for tens of thousands of students per year worldwide is that: first, there is a well-functioning market and second ... a whole lot of 'disturbing things', without, however, any relevance for the genuinely positive working of the 'market'.

Releasing tens of thousands of students into a complex professional world with this message in mind is probably the true disaster and tragedy of mainstream economics.

As an example that Steve Keen (2009) has nicely presented, Varian, in his Intermediate Microeconomics (2006), discusses homothetic preferences over several pages, concluding they are not very realistic (p. 102). Then Varian rightly notes that aggregate demand will generally depend on prices and income distribution in a circular way (with identical reproduction - that is, an equilibrium in no way guaranteed: Sraffa's issue), before continuing that it is just 'convenient to think of the aggregate demand as the demand of some representative consumer who has an income that is just the sum of all individual incomes. The conditions under which this can be done are rather restrictive', and ends in the typical way of modern mainstream textbooks: '... a complete discussion of this issue is beyond the scope of this book' (p. 276). From there onwards, Varian just claims repeatedly: 'The market demand curve is simply the sum of the individual demand curves' (p. 281). 


\section{MAINTAINING THE 'CITADEL'S ROLE AS THE PRIME IDEOLOGY PROVIDER: THE COUNTER-ATTACK OF RANKING AS PERSONNEL REPRODUCTION AND IDEOLOGICAL CLEANSING}

In all, there appears to be little indication that the dominance of the mainstream and its involvement with vested interests is attenuating. Rather, the uneven contest takes place in a new field, where powerful relief forces for the citadel and a potential deadly attack on the heterodoxies have been set up: evaluation and ranking.

Evaluating economic research is, of course, a contested field as well, and particularly so because of the surprisingly misconceived and erroneous ranking procedures for journals, departments and individual scholars - and the careers of a whole generation of critical young economists are at stake here.

What has been made out of the complex issues of evaluating research quality is reducing them to the simplistic and mistaken procedure of a one-dimensional ranking of quantitative dominance, a cumulative, self-referencing dictatorship of mere mass, eventually leading the whole discipline into a severe and tragic lock-in.

Among many other things, it has been demonstrated that there are straightforward path-dependent effects - herd behavior, one might say - in the citation culture: oftencited papers and authors are cited more often - that is, the fame of papers and authors has lasting increasing returns to scale (see, for example, Tol 2007).

The practice of peer reviewing has also come under scrutiny in this context. For instance, Chubin and Hackett in their book Peerless Science (1990) reported 'that only $8 \%$ of the members of the Scientific Research Society agreed that peer reviews work well as it is' (p. 192). Also, for instance, Bruno Frey, in a much cited paper on 'Publishing as prostitution' (2003: 206), stated that authors have to slavishly follow the demands of anonymous referees, who do not have a responsibility for or commitment to the journal, nor the publication and knowledge generation process as a whole. In fact, there are many case studies which have ascertained that 'peer review lacks validity, impartiality, and fairness' (Seidl et al. 2005: 506).

Andrew Oswald found, in the official run-up to the British Research Assessment Exercise (RAE) 2008, that 'the publication system is full of errors' (Oswald 2006: 9). It would routinely put low-quality papers into the top-ranked journals. He concluded: 'Unless hiring committees, promotion boards and funding bodies are aware of this fact, they are likely to make bad choices about whom to promote and how to allocate resources' (Oswald 2006: 9).

On top of that, journal impact factor calculations are done in disturbingly unprofessional ways, subject to many misconceptions, data and processing failures. The International Mathematical Union, the International Council of Industrial and Applied Mathematics and the international Institute of Mathematical Statistics have argued in a joint report released in 2008 that the belief that citation statistics are accurate measures of scholarly performance is unfounded, the use of such statistics is often highly subjective, the validity of these statistics is neither well understood nor well studied, and that sole reliance on citation data provides at best an incomplete and often shallow understanding of research (Adler et al. 2008: 2).

Many have also shown that citation impacts vary considerably across different bibliographic sources, such as Econlit, JSTOR, Scopus, or Google Scholar, with major impacts particularly on the ranking positions of heterodox journals and scholars (see, for example, D'Orlando 2009; the many papers of Loet Leydesdorff, the related works of Fred Lee, and the special issues he edited with me, Elsner/Lee 2008; Lee/Elsner 2010). Again, heterodox themes, fields and authors do vary 
drastically in attention and rankings, depending on the databases of the different rankings.

Harry Bloch, a heterodox colleague involved at a high level in the official Australian ranking procedure, has repeatedly demonstrated the built-in biases that favour abstract theory and econometrics over applied and policy-relevant research (Bloch 2010).

And, in fact, we do hear about related acts of censorship in Australia against wellknown heterodox colleagues such as Steve Keen or Clive Spash through local administrations or the national governmental research organization. And within our associations, among them EAEPE, we have increasingly received information from many parts of the world about attempts of the mainstream at ideological cleansing of departments and faculties. For the USA, the contested histories of UMass Amherst became famous, and the execution of the progressive econ department at Notre Dame, IN, notorious among many other more or less silent cases of corporate-conform or fundamentalist streamlining of departments and of corresponding individual fates of critical economists. We also hear disturbing facts of merely ideological suspicion and prosecution of colleagues, and ideological cleansing of departments from Eastern European countries, and also from Turkey.

The time seems to be more than ripe for more and real pluralism in economics, as even The Times has put it: 'Now is the time for a revolution in economic thought' (Kaletsky 2009b).

We would, of course, not expect this to materialize in the foreseeable future. So we need to continue with our critiques, to push alternative impact measures and rankings, promote alternative and multiple rankings, and demonstrate the factual multiplicity of rankings as used in different countries and scientific communities, and as demonstrated by the Australian Harzing lists (see http://www.harzing.com/jql.htm).

In the UK, the Association for Heterodox Economics (AHE) has made a first and successful attempt at getting officially heard as a voice in the British RAE procedures. The Australian Society of Heterodox Economics (SHE) is petitioning for the same.

We also need to push ethical issues of the practice of publication in the mainstream, such as conflicts of interest, data transparency and the reproducibility of calculation results - see the topical Reinhart-Rogoff case - which enjoyably have recently been pushed by the American Economic Association (in 2011), and indeed appear to be mainly mainstream problems.

But above and beyond that, we need to further develop heterodox identities and exemplify a culture of active pluralism.

\section{THE IDENTITIES AND PLURALISM OF HETERODOXIES - MORE THAN JUST PLURALITY? COMMON THEMES, CONVERGENCE, COLLABORATION?}

But isn't the mere term 'heterodoxy' itself already a signal of a cemented minority position and an indication of our minority identity, as many critical economists suspect? Many of them prefer the self-designation of being pluralist rather than heterodox. I personally have preferred to have my heterodox textbook (Elsner 2012) sailing under the flag of complexity economics. We might also experiment with the idea of real-world economics, in the sense of a superior 'fitness for purpose' (see the CfP of this conference), of superior applicability to action, behavior, strategy and policy, or of a true interdisciplinarity, beyond just physics, math and computer science - that is, with psychology, biology, brain sciences, anthropology, history, sociology, political science, philosophy, etc. 
Beyond that, what are the substantial vanishing points of our proactive pluralism and our hoped-for networked convergences? (Note: convergences, not unification or conformity.) The conferences and publications on heterodox pluralism have been abundant in recent years; and there are heterodox conferences on a new curriculum as well. We have handbooks and journals on heterodox pluralism and education. Edward Fullbrook and Jack Reardon, for instance, are leading figures who have developed this field.

One of the theoretical fields of the original attack of the neoclassical mainstream in the phase of colonizing economics was the microfoundations issue, where they claimed to have the better, and, in fact, the only microfoundation. This, of course, was bluntly misconceived. What they had was simplistic, unrealistic, inconsistent and unfruitful. John King has recently published the book The Microfoundations Delusion (King 2012) and Duarte and Lima have recently edited Microfoundations Reconsidered (Duarte/ Lima 2012), both in an attempt to set these things right for heterodox progress.

So both an effective 'counterattack' and an important vanishing point of heterodox convergences appear to me to be the continuing microfoundations of macro and the related macrofoundations of micro projects. With the first, we deal with complex and demanding processes of structural emergence; with the second, with what Geoff Hodgson coined a reconstitutive downward causation. The latter would include the normative, incentives and behaviours shaping effects of (informal or formal) rules and institutions, but also of belief systems and ideologies, or of distinguishable systemic macro constellations.

Others have elaborated on specific convergences, such as Reynold Nesiba has recently done with respect to Institutionalist and Post-Keynesian convergence on 'modern monetary theory' (Nesiba 2013).

I have received a paper recently for the Forum of Social Economics that I edit, from a young scholar investigating 'the transdisciplinary field of heterodox economic studies'. He develops the idea of intellectual Kula rings - that is, systems of reciprocity over time and space used in the Trobriand Islands, cited by Karl Polanyi as a mode of societal exchange. The practice of systems of exchange of non-equivalents or incommensurables has existed for a long time among our ranks, but needs to be further developed. The practice exists in the USA in the frame of the Allied Social Science Associations (ASSA), Western Social Science Associations (WSSA) and the Eastern Economic Association (EEA), among other diverse heterodox associations such as the AFEE, URPE, ASE, AFIT, IAFFE, etc. We do not have that tradition in Europe yet. But a first promising attempt has been made in Paris 2012 with a joint conference of the AHE, EAEPE, IIPPE and AFEP together with several journals. Also, the large heterodox macroeconomic and macro-policies network, FMM, has been doing very well in recent years. Finally, we have prepared a broader participation of heterodox associations and journals at the annual EAEPE conference in Paris 2013, with panels on heterodox convergence and collaboration, publication strategies for young scholars, business models of heterodox journals, etc. This is the path we have to follow, to intensify the intellectual Kula ring exchange.

\section{REFERENCES}

Adler, R., Ewing, J., Taylor, P. (2008): Citation statistics: a report from the International Mathematical Union in cooperation with the International Council of Industrial and Applied Mathematics and the Institute of Mathematical Statistics, URL: http:/www.mathunion.org/ fileadmin/IMU/Report/CitationStatistics.pdf. 
Albin, P., Foley, D. (1998): Introduction to 'barriers and bounds to rationality', in: Foley, D.K. (ed.), Barriers and Bounds to Rationality: Essays on Economic Complexity and Dynamics in Interactive Systems, by Albin, P.S., with an Introduction by Foley, D.K., Princeton, NJ: Princeton University Press, 3-72.

Allais, M. (1953): Le comportement de l'homme rationnel devant le risque: critique des postulats et axiomes de l'école Américaine, in: Econometrica, 21(4), 503-546.

Bloch, H. (2010): An uneven playing field: rankings and ratings for economics in ERA 2010, in: Economic Papers: A Journal of Applied Economics and Policy, 31(4), 418-427.

Buchanan, M. (2008): This economy does not compute, in: The New York Times, op-ed, 1 October.

Buiter, W. (2009): The unfortunate uselessness of most 'state of the art' academic monetary economics, in: The Financial Times, 3 March, URL: http://blogs.ft.com/maverecon/2009/03/ the-unfortunate-uselessness-of-most-state-of-the-art-academic-monetary-economics/.

Chubin, D.E., Hackett, E.J. (1990): Peerless Science: Peer Review and U.S. Science Policy, New York: State University of New York Press.

Coase, R. (2012): Saving economics from the economists, in: Harvard Business Review, 12-2012, URL: http://hbr.org/2012/12/saving-economics-from-the-economists (accessed 21 June 2013).

Cohen, P. (2009): Ivory tower unswayed by crashing economy, in: The New York Times, 4 March, URL: http://www.nytimes.com/2009/03/05/books/05deba.html?_r=1.

Dahlem Report (2009): URL: http://www.google.de/url? sa=t\&rct=j\&q=\&esrc=s\&source= web\&cd=1\&ved=0CC8QFjAA\&url=http $\% 3 \mathrm{~A} \% 2 \mathrm{~F} \% 2 \mathrm{~F}$ citeseerx.ist.psu.edu $\% 2 \mathrm{Fviewdoc} \%$ 2Fdownload\%3Fdoi\%3D10.1.1.148.56\%26rep\%3Drep1\%26type\%3Dpdf\&ei=FlDcUZW xE8vFtAaTwQE\&usg=AFQjCNHa5IH3Pz04oTbWG_0L46Z4C61GAQ\&bvm=bv.48705608, d.Yms.

D’Orlando, F. (2009): Electronic resources and heterodox economists, University of Cassino, Department of Economics Science Working Paper 2/2009, URL: http://dipse.unicas.it/files/ wp200902.pdf.

Duarte, P.G., Lima, G.T. (eds) (2012): Microfoundations Reconsidered: The Relationship of Micro and Macroeconomics in Historical Perspective, Cheltenham, UK, Northampton, MA, USA: Edward Elgar.

Elsner, W. (2012): Microeconomics of Interactive Economies. Evolutionary, Institutional, and Complexity Perspectives: An Intermediate 'Non-Toxic' Textbook, Cheltenham, UK, Northampton, MA, USA: Edward Elgar.

Elsner, W., Lee, F.S. (eds) (2008): Publishing, refereeing, rankings, and the future of heterodox economics, in: On the Horizon, Special Issue, 16(4), 176-297.

Feiner, S. (2008): Coping with post-autistic economics, URL: http://tpmcafe.talkingpointsmemo.com/ 2008/08/15/coping_with_postautistic_econo/.

Foster, J. (2005): From simplistic to complex systems in economics, in: Cambridge Journal of Economics, 29, 873-892.

Frey, B. (2003): Publishing as prostitution? Choosing between one's own ideas and academic failure, Public Choice, 116(1-2), 205-223.

Kaletsky, A. (2009a): Economists are the forgotten guilty men, in: The Times, Timesonline, 5 February, URL: http://www.timesonline.co.uk/tol/comment/columnists/anatole_kaletsky/ article5663091.ece.

Kaletsky, A. (2009b): Now is the time for a revolution in economic thought, in: The Times, Timesonline, 9 February, URL: http://www.timesonline.co.uk/tol/comment/columnists/ article5689642.ece.

Kapeller, J. (2012): Modell-Platonismus in der Oekonomie: Zur Aktualität einer klassischen epistemologischen Kritik, in series: Institutionelle und Sozial-Ökonomie, Elsner, W. (ed.), Vol. 20, Frankfurt/M.: P. Lang.

Kapeller, J. (2013): 'Model-Platonism' in economics: on a classical epistemological critique, in: Journal of Institutional Economics, 9(2), 199-221.

Keen, S. (2009): A pluralist approach to microeconomics, in: Reardon, J. (ed.), The Handbook of Pluralist Economics Education, London, New York: Routledge, 120-149.

Kessler, A. (2010): Cognitive dissonance, the Global Financial Crisis and the discipline of economics, in: Real-World Economic Review, 54, 2-18. 
Keynes, J.M. (1936): The General Theory of Employment, Interest and Money, London: Macmillan.

King, J.E. (2012): The Microfoundations Delusion: Metaphor and Dogma in the History of Macroeconomics, Cheltenham, UK, Northampton, MA, USA: Edward Elgar.

Kurz, H. (2010): On the dismal state of a dismal science?, in: Investigación Económica, LXIX(274), 17-41, URL: http://www.redalyc.org/pdf/601/60115471001.pdf (accessed 9 July 2013).

Lee, F.S., Elsner, W. (eds) (2010): Evaluating economic research in a contested discipline: rankings, pluralism, and the future of heterodox economics, in: Studies in Economic Reform and Social Justice, Wiley-Blackwell Publishing, special Issue of the American Journal of Economics and Sociology, 69(5).

Lucas, R. (2003): Macroeconomic Priorities, presidential address to the American Economic Association, American Economic Review, 93(1), 1-14, URL: http://ideas.repec.org/a/aea/ aecrev/v93y2003i1p1-14.html (accessed 9 July 2013).

Lucas, R. (2004): My Keynesian education, in: De Vroey, M., Hoover, K. (eds), The IS-LM Model: Its Rise, Fall and Strange Persistence, Annual Supplement to Vol. 36 of History of Political Economy, Durham: Duke University Press.

Modigliani, F. (1987): My evolution as an economist, in: Breit, W., Hirsch, B.T. (eds), Lives of the Laureates: Twenty-three Nobel Economists, Cambridge, MA and London, UK: The MIT Press, 5th edn 2009, 115-136, URL: http://de.scribd.com/doc/52047336/lives-nobel-laureates (accessed 9 July 2013).

Nadeau, R. (2008): The economist has no clothes, in: Scientific American, 298(4), 42.

Nesiba, R. (2013): Do Institutionalists and post-Keynesians share a common approach to Modern Monetary Theory (MMT)?, in: European Journal of Economics and Economic Policies, $10(1), 44-60$.

Oswald, A. (2006): Prestige labels, in: Royal Economic Society Newsletter, 135, 7-10.

Palley, T.I. (2013): Gattopardo economics: the crisis and the mainstream response of change that keeps things the same, in: European Journal of Economics and Economic Policies, 10(2), 193-207.

Ramazzotti, P., Elsner, W., Frigato, P. (eds) (2012): Social Costs Today: Institutional Analyses of the Present Crises, London and New York: Routledge, Routledge Frontiers of Political Economy 159.

Seidl, C., Schmidt, U., Groesche, P. (2005): The performance of peer review and a beauty contest of referee processes of economics journals, in: Estudios de Economia Aplicada, 23(3), $505-551$.

Sraffa, P. (1926): The laws of returns under competitive conditions, in: Economic Journal, 36(144), $535-550$.

Tol, R.S.J. (2007): The Matthew Effect defined and tested for the 100 most prolific economists, in: Journal of the American Society for Information Science and Technology, 60(2), 420-426.

Varian, H. (2006): Intermediate Microeconomics: A Modern Approach, New York: W.W. Norton, 7 th edn.

Wellhöner, V. (2002): Oekonomik - Physik - Mathematik: Die Allgemeine Gleichgewichtstheorie im interdisziplinären Kontext, Frankfurt/M.: P. Lang.

Young, A.A. (1928): Increasing returns and economic progress, in: The Economic Journal, 38(152), $527-542$. 